\title{
FOGYASZTÓI MAGATARTÁSI TRENDEK A HAGYOMÁNYOS MAGYAR TERMÉKEK PIACÁN
}

\author{
'Dr. Ferencz Árpád PhD-²Dr. Nótári Márta PhD \\ 'föiskolai tanár, Kecskeméti Föiskola Kertészeti Föiskolai Kar, Kecskemét \\ ${ }^{2}$ föiskolai docens, Kecskeméti Fõiskola Kertészeti Föiskolai Kar, Kecskemét
}

\section{SUMMARY}

The only products, which can meet the high demands of the Common Market are the ones which have added values and are in conformity with the quality and safety conditions of the food industry. Such products are what we consider the traditional products and we have to do our best to improve our activities in order to find markets for them. Accordingly, we have made researches regarding the habits, preferences and lifestyle of customers, who purchase Hungarian products of gardening and food industry. There is no usable result in every case from marketing aspect given by the classical socio-demographic segmentation method. It is stated that consumers with analogous demographic situation purchase diverse products. The main motive of the deviation is the personal lifestyle. The lifestyle of consumers of horticultural and food industrial the Hungarian traditional products were examined and analyzed in the study.

Kulcsszavak: fogyasztói magatartás, tradicionális magyar termékek

\section{BEVEZETÉS}

Az Európai Unióban folyamatosan nő a vásárlỏi és fogyasztói érdeklődés az egyedi, hagyományos termékek iránt. Ez a felmérések szerint a teljes vásárlásnak a 12,4\%-kát jelenti. A vásárlói tanulmány szerint a legtöbb vásárló hisz a jelölésekben, márkákban, mert ezekben kiváló értéket kapnak a pénzükért. Ha az ár ugyanaz, a kisebb elöállítót és a speciálisabb terméket választják, mert ott magasabb minöséget képzelnek el.

Kozák (2007) szerint mindez magyarázható azzal a jelenleg határozottan megfigyelhető trenddel, amely szerint a magas minöségü élelmiszerek fogyasztásával hosszabb távon jobban jár a fogyasztó. Más kutatások szintén alátámasztják ezt az eredményt, vagyis, hogy a fogyasztók számára az elsődleges szempont a minőség.

A fogyasztói magatartáskutatás alapvetően arra irányul, hogy feltárja a konkrétan megvalósuló magatartás mögött húzódó okokat és azokra magyarázatot tudjon adni. Mindezen ismeretek birtoklása nélkül lehetetlen a vásárlási döntési folyamat megismerése, valamint a reménytelen vállalkozást felmérni a marketing környezet hatását a fogyasztói és vásárlói döntésekre. Horváth (1996) szerint a fogyasztói magatartást a „Fogyasztón kívüli tényezőkre (kultúra, szubkultúra, társadalmi osztályok) és a „Fogyasztón belüli (lélektani) tényezőkre (érzelem, motiváció, beállítottság, emlékezés, személyiség, stb.) lehet sorolni.

Töröcsik (2007) megállapítása miszerint a vásárlói és fogyasztó kategória elkülönithető a marketingben, ugyanis a vásárlást végző személy nem mindig vagy nem egyedüli fogyasztója az adott terméknek, és az sem szükségszerü, hogy ő hozza meg a végső döntést.

\section{ANYAG ÉS MÓDSZER}

\subsection{A FELMÉRÉS KÖRÜLMÉNYEI}

2010-2011. évben primer kutatásokat végeztünk a kertészeti és élelmiszeripari hungarikumok fogyasztók fogyasztói magatartásának és életstílusának elemzésére. A mintákat a Központi Statisztikai Hivatal adatai alapján súlyozottan gyüjtöttük. A programunkba bevittünk 852 kérdöív adatait és feltételeket adtunk meg az SPSS programnak (select variable). Ez lehetőséget nyújt arra, hogy a megadott feladattömbből kiszürje a nem szükséges adatokat. Így az alapsokaság összetétele megfelelt a KSH népesség nyilvántartás 
összetételének. A mintánk így közel reprezentatív lett, azaz 713 minta elemszám alapján az egész magyar népességre következtetéseket tudtunk levonni.

\subsection{VIZSGÁLATI MÓDSZEREK}

A piackutatás mai piaci jelenségek szervezett és módszeres vizsgálatát jelenti. Az vizsgálat kiterjed azon tényezőkre, amelyek a felhasználó számára fontosak lehetnek a piaci munka számára (Domán et al.,2009). A megkérdezéses eljárások közül a standard interjú eszközeként a standard kérdőívezés írásbeli megkérdezés módszerét alkalmaztuk. A kutatás saját készítésü kérdőíves felmérésen alapult. A kérdések nagyobb részével az élelmiszerfogyasztásra, azt meghatározó befolyásoló tényezőkre, kisebb hányadával pedig az egészséges táplálkozással kapcsolatos ismeretekre helyeztük a hangsúlyt.

\section{EREDMÉNYEK}

$\mathrm{Az}$ 1. ábra szerint a megkérdezettek számára vásárlásnál a legfontosabb befolyásoló és meghatározó tényező az íz. A második helyen az ár, amely erősen meghatározza, hogy mi kerül be a vásárlói kosárba. Ma a gazdasági válság közepén az embereket még a korábbinál is nagyobb mértékben befolyásolja a megvásárolandó termék ára. Ez elősegítheti a multi cégek erősödését, hiszen nagyobb akciókkal tudják a vásárlókat magukhoz vonzani, mint például az őstermelők. A minőséget, a márkát, valamint a kiszerelést a válaszadók közepes mezőnybe helyezik.

\section{1. ábra: Az élelmiszervásárlást befolyásoló tényezők}

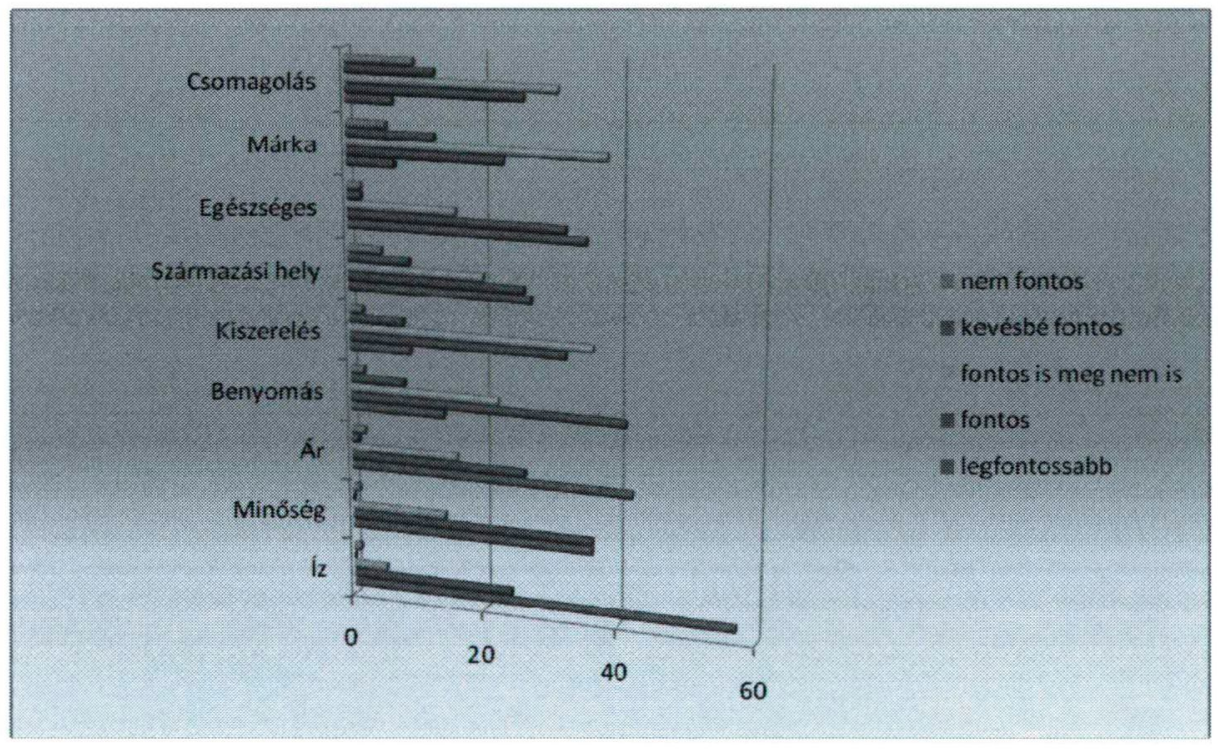

Forrás: Saját szerkesztés, 2012

A táplálkozási trend vizsgálati eredményét a 2. ábra szemlélteti. A megkérdezettek 48\%-a próbál rendszeres és tudatos étkezést folytatni. Az emberek számára szükséges lenne a rendszeres és tudatos táplálkozásra, de sajnos ezt az étkezést a válaszadók csak 19\%-a jelölte meg. A válaszadók 33\%-a annyit eszik amennyi jól esik, ez jól mutatja, hogy az étkezés számukra csak a szükséglet kielégítését jelenti és nem elsődleges a rendszeres és tudatos táplálkozás. 


\section{2. ábra: Rendszeres és tudatos táplálkozás megoszlása a megkérdezettek körében}

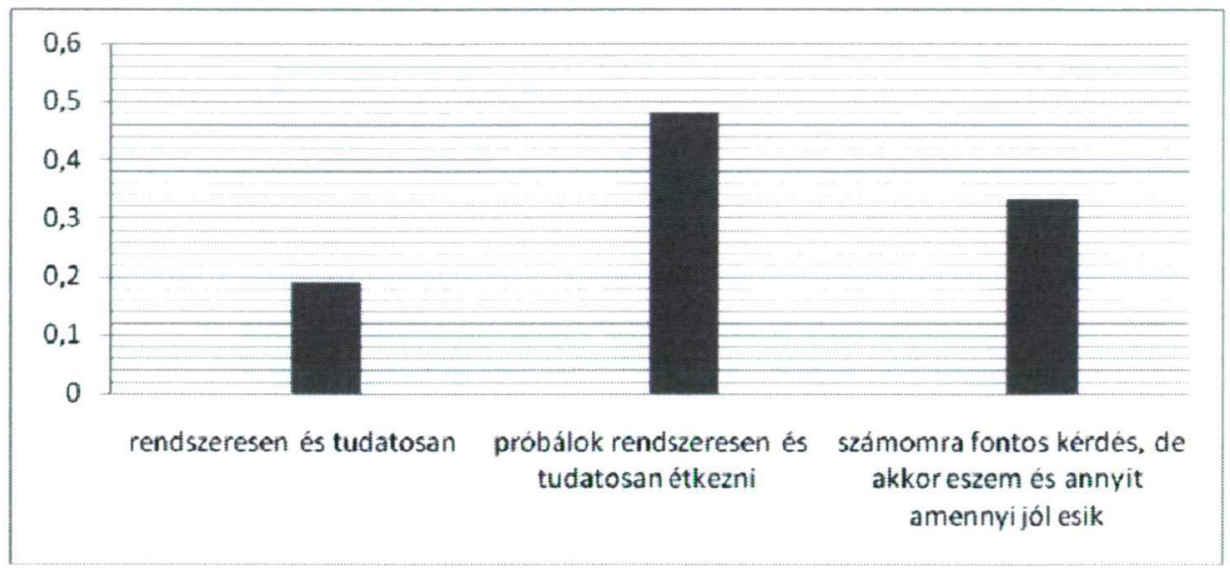

Forrás: Saját szerkesztés, 2012

A 3. ábra alapján elmondható, hogy a válaszadók közel fele a legegészségesebb élelmiszerek közé a zöldség, gyümölcs, valamint a tejtermékeket sorolja. Ezt követik az egészséges élelmiszerek, mint a biotermékek és az otthon előállított élelmiszerek. Kevesen gondolják úgy, hogy a teljes kiőrlésủ élelmiszerek egészségesek.

\section{3. ábra: Mit tart egészsége szempontjából megfelelő élelmiszernek?}

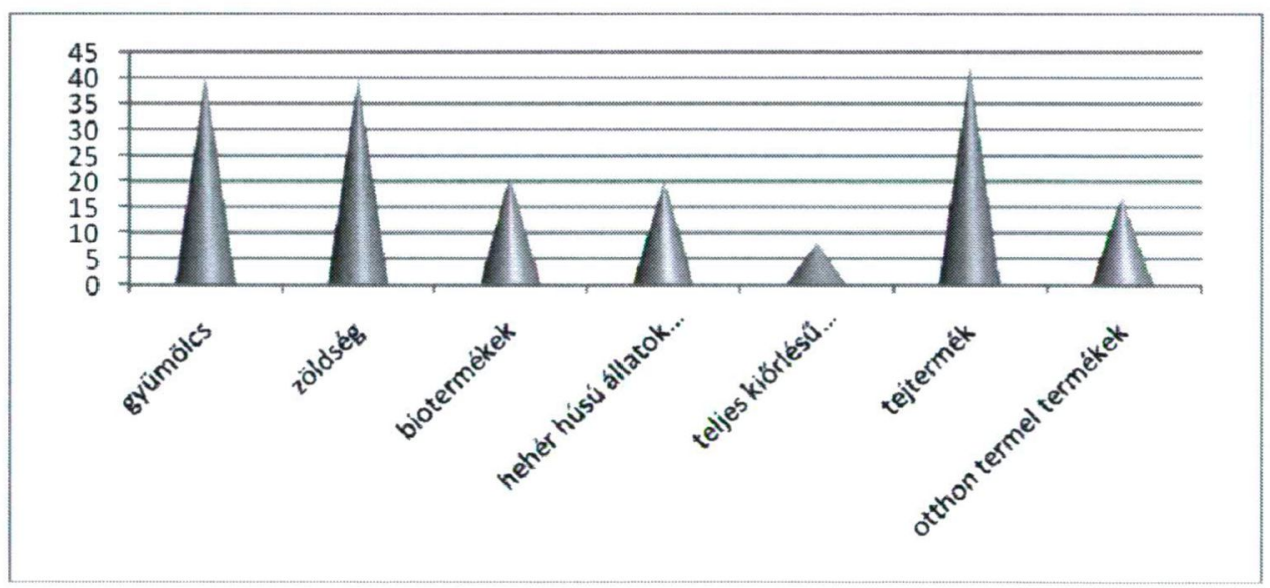

Forrás: Saját szerkesztés, 2012

Kutatásunk során 12 féle élelmiszer-fogyasztási gyakoriságát vizsgáltuk. Az eredményeket a 4. ábra mutatja be. A zöldség és gyümölcs fogyasztásának gyakorisága megegyezik. E két élelmiszer rostban gazdag, ezért is nélkülözhetetlen a szervezet számára ennek ellenére a kitöltők csak $40 \%$-a fogyasztja naponta. Csak egy alkalommal hetente $10 \%$ fogyasztja. A burgonyát és a tésztaféléket azonos gyakorisággal fogyasztanak. A levesek, húsételek, és húsfélék fogyasztása esetén hasonlóság mutatkozik. Naponta $25 \%$-uk fogyaszt ilyen ételeket, körülbelül 45-50\%-uk hetente többször. A tojásfogyasztásra a legjellemzőbb a heti 1-2 alkalom. A tejtermékek fogyasztását elemezve látható, hogy $50 \%$-uk fogyaszt tejet. A 
biotermékek valamint a barna kenyér fogyasztása megoszlik. Az ábráról leolvasható, hogy a kitöltők 20\%-a egyáltalán nem fogyaszt ilyen terméket.

\section{4. ábra: Az élelmiszerek fogyasztásának gyakorisága}

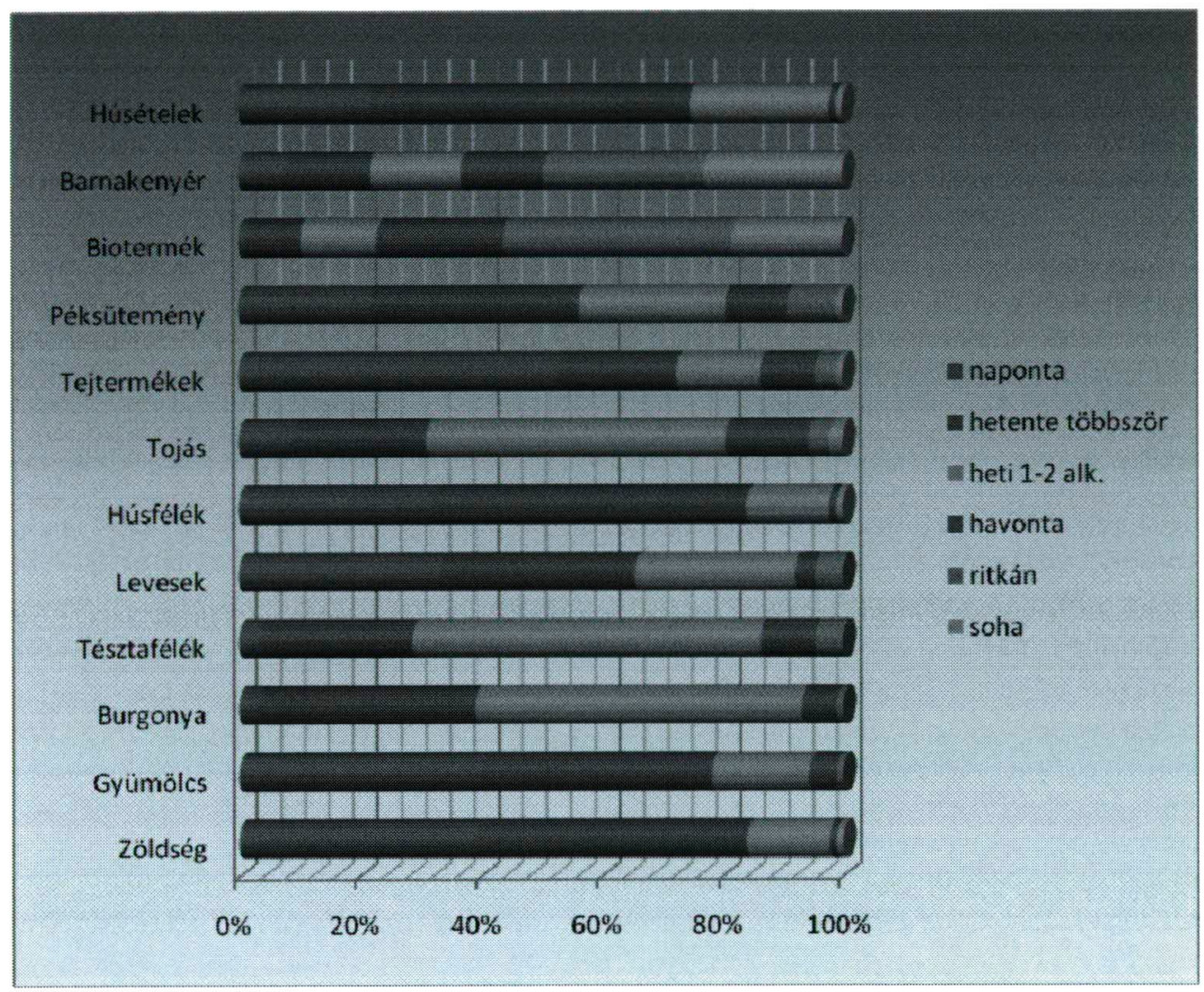

Forrás: Saját szerkesztés, 2012

\section{KÖVETKEZTETÉSEK, JAVASLATOK}

Az élelmezés- és táplálkozáspolitika (ÉTP) kormányzati szinten irányított összehangolt tevékenységek összessége, amely az egész lakosság elegendő mennyiségü és megfelelö minőségű táplálékkal történő ellátására irányul. Más szóval: az ÉTP lehetővé teszi, hogy érvényre jusson az egészséges táplálkozáshoz való emberi jog. Feladata nemcsak az élelmezés, azaz a lakosság táplálékkal való ellátása, hanem az egészség megtartása, betegségek megelőzése a helyes táplálkozás révén (Zajkás, 2004). Az átgondolt, figyelmesen megtervezett és megszervezett, rendszeresen ellenőrzött, értékelt program elsődleges célja az idült, nem fertőző, táplálkozással összefüggő betegségek kockázatának csökkentése, a lakosság egészségi állapotának javítása, a táplálkozással összefüggő betegségek okozta mortalitás csökkentése és a várható élettartam megnövelése. E fö célok elérésének megvalósítását a fő irányvonalak kidolgozása és alkalmazása teszi lehetővé.

$\mathrm{Az}$ átgondolt, figyelmesen megtervezett és megszervezett, rendszeresen ellenörzött, értékelt program elsődleges célja az idült, nem fertőző, táplálkozással összefüggő betegségek kockázatának csökkentése, a lakosság egészségi állapotának javítása, a táplálkozással összefüggő betegségek okozta mortalitás csökkentése és a várható élettartam megnövelése. $\mathrm{E}$ 
fö célok elérésének megvalósitását a fö irányvonalak kidolgozása és alkalmazása teszi lehetővé az alábbiak szerint:

- A szakemberek táplálkozástudományi ismereteinek jelentős növelése az elkövetkező 5 év során és ezzel egy időben a lakossági táplálkozási ismeretek intenzív elterjesztése, kiemelten a gyermekek oktatásában.

- Folyamatos adatgyüjtés és tájékozódás a lakosság táplálkozásáról, élelmiszer választékáról.

- A táplálkozástudományi kutatások támogatása a táplálkozás, életmód, betegség, egészség kapcsolatának jobb megértése és a stratégiák szükségszerü módosítása érdekében.

- Az egészséges táplálkozáshoz szükséges élelmiszer választék kialakítását ösztönzö támogatási rendszer létrehozása és ennek folyamatos hosszú távú müködtetése.

- Az egészséges táplálkozás alapvető emberi jog, és a legszegényebbek számára is meg kell teremteni e jog gyakorlásának gazdasági és társadalmi feltételeit.

- Az egészséges táplálkozás megvalósításához szükséges alapvető élelmiszerek mindenhol és mindig eiérhetők legyenek.

\section{FELHASZNÁLT IRODALOM}

Domán Sz. - Tamus A. (2009): Marketing Alapismeretek Károly Róbert Kutató- Oktató Közhasznú Nonprofit Kft. Gyöngyös

Gfk Piackutató Intézet (2009): Étkezési szokások - te hol helyezkedsz el a "felsö plusz" és az "underclass" között? Gfk Hungária

Guerro L.- Colomer, J.-Guardia, D.- Xicola, J. (2004): Comsumer Attitude Towards Brands Food Quality and Preference Vol. 11. No.5. pp. 387-395

Kotler P. (2002): Marketing menedzsment KJK-Kerszöv Jogi és Üzleti Kiadó Kft. Budapest

Kozák Ȧ. (2007): Étkezési szokások: Tudatos a fogyasztó? Gfk Hungária

Lehota J. (2001): Élelmiszer-gazdasági marketing Müszaki Könyvkiadó, Budapest

Lehota J. (2004): Az élelmiszer-fogyasztói magatartás hazai és nemzetközi trendjei Élelmiszer, táplálkozás és marketing 2004/1 Kaposvár

Rützler, H. (2005): Megatrends der Esskultur, Biofach, Nünberg

Szakály Z.(2011): Táplálkozásmarketing Mezögazda Kiadó Budapest

Töröcsik M. (2007): Foodtrendek és trendi vásárlói csoportok. Acta Oeconomica, Kaposvár Zajkás G. (2004): Magyarország Nemzeti Táplálkozáspolitikája. Nemzeti Népegészségügyi Program Budapest Vol. 8-9. pp. 12-13. 